\title{
YAQUI AND THE ANALYSIS OF PRIMARY OBJECT LANGUAGES ${ }^{1}$
}

\author{
LILIÁN GUERRERO \\ University at Buffalo, State University of New York \\ UNIVERSIDAD DE SONORA \\ Robert D. VAN VALin, JR. \\ University at Buffalo, State University of New York
}

\begin{abstract}
The central topic of this study is to investigate three- and four-place predicate in Yaqui, which are characterized by having multiple object arguments. As with other Southern Uto-Aztecan languages, it has been said that Yaqui follows the Primary/Secondary Object pattern (Dryer 1986). Actually, Yaqui presents three patterns: verbs like nenka 'sell' follow the direct-indirect object pattern, verbs like miika 'give' follow the primary object pattern, and verbs like chijakta 'sprinkle' follow the locative alternation pattern; the primary object pattern is the exclusive one found with derived verbs. This paper shows that the contrast between direct object and primary object languages is not absolute but rather one of degree, and hence two "object" selection principles are needed to explain this mixed system. The two principles are not limited to Yaqui but are found in other languages as well, including English.

[KEYWORDS: multiple object constructions, primary object languages, dative shift, Role and Reference Grammar, Uto-Aztecan languages]
\end{abstract}

1. Introduction. Many verbs have more than one option for the expression of their arguments and, consequently, may occur in more than one syntactic pattern. For example, English give and present may either code the theme as the direct object and the RECIPIENT ${ }^{2}$ as the indirect object, as in $(1 a)$ and $(2 a)$, or may code the RECIPIENT as the first object $(1 b)$ and the direct object $(2 b)$. A similar phenomenon is observed with verbs like load which

\footnotetext{
${ }^{1}$ Earlier versions of this paper were presented at the Niagara Linguistic Society (November 2001) and the Role and Reference Grammar Conference (July 2002). Comments from the participants have been very helpful. We are indebted to Beth Levin, Matthew Dryer, and JeanPierre Koenig for their valuable comments on preliminary versions of this work. We also thank two anonymous referees. None of them, however, should be held accountable for our views or mistakes. Lilián Guerrero is grateful to CONACyT (116366) and PROMEP (UNISON 991401), as well as the Mark Diamond Research Fund and the College of Arts and Sciences Dissertation Fellowship at the University at Buffalo, which funded in part the research on Yaqui.

${ }^{2}$ We use RECIPIENT as a cover term for the cluster of thematic relations, i.e., recipient, goal, source, experiencer, and addressee, which co-occurs with a theme with three-argument verbs.
}

[IJAL, vol. 70, no. 3, July 2004 , pp. 290-319]

(C) 2004 by The University of Chicago. All rights reserved.

0020-7071/2004/7003-0004\$10.00 
may code the theme as the direct object and the location as a locative argument marked by on $(3 a)$ or the location as the direct object and the theme as an oblique argument marked by with $(3 b)$.

(1a) Goyo gave the flowers to his mother.

(1b) Goyo gave his mother the flowers.

(2a) Goyo presented the flowers to his mother.

(2b) Goyo presented his mother with the flowers.

(3a) Goyo loaded the hay on the truck.

(3b) Goyo loaded the truck with the hay.

In Yaqui, there are three types of three-argument verbs. ${ }^{3}$ The first type codes the theme as an argument marked by the accusative suffix $-t a,{ }^{4}$ while the RECIPIENT is marked by the adposition $-u$ after $-t a$, as in $(4 a)$. The second type codes both the theme and RECIPIENT as accusative core arguments, as in $(4 b)$. For these verbs, only one of these case arrangements is permitted. ${ }^{5}$

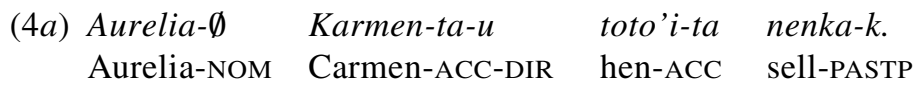

'Aurelia sold the hen to Carmen'.

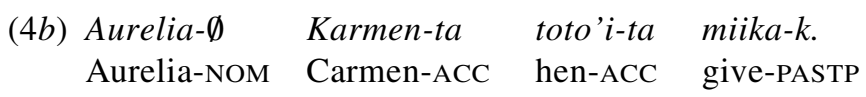

'Aurelia gave Carmen the hen'.

The third type shows a coding alternation. In $(5 a)$, the theme is coded as the direct object while the location is marked by the locative postposition

\footnotetext{
${ }^{3}$ Yaqui was traditionally spoken by the Yoeme people living along the Rio Yaqui, in Sonora, México. After the Mexican Revolution in 1920, a large group of speakers settled in Arizona. Today, there are approximately 15,000 speakers in Sonora and an estimated 6,000 in Arizona (Estrada 1998). The data in this paper come mainly from our own fieldwork on the Sonora dialect. Special thanks to Gregorio Flores and his family, as well as Crescencio Buitimea, Asalia Buitimea, and Anabela Carlón, who kindly shared the knowledge of their language with us.

${ }^{4} \mathrm{~A}$ reviewer has pointed out that the suffix -ta codes not only the theme/patient of transitive verbs, it also marks the possessor NP in genitive phrases and the subject in relative and complement clauses. Also, the directional postposition $-u$, the comitative -mak, the instrumental -(a)e, the benefactive -betchi'ibo, and the locative -betuk all require accusative complements marked by - $t a$ when their object is a NP (specially when animate); when the object is pronominal, there is a set of object of postposition pronouns different from the accusative one. Because - $t a$ serves the canonical function of the accusative case, namely, to mark the patient/theme of a transitive verb, we henceforth refer to it as the "accusative" case.

${ }^{5}$ Abbreviations are as follows: $\mathrm{ACC}=$ Accusative, $\mathrm{APL}=$ Applicative, $\mathrm{CAUSE}=$ Causative, $\mathrm{COM}$ $=$ Comitative, DIR $=$ Directional, EXPECT $=$ Expected, INST $=$ Instrumental, LOC $=$ Locative, NEG $=$ Negation, NOM $=$ Nominative, PASS $=$ Passive, PASTP $=$ Past perfective, PL $=$ Plural, POSS $=$ Possessive, PRES $=$ Present, PSA $=$ Privileged Syntactic Argument, REL $=$ Relativizer, SG $=$ Singular
} 
-po. In (5b), the location is coded as the direct object and the theme is marked by the instrumental postposition - ae .

$\begin{array}{llll}\text { Empo } & \text { kafe-ta } & \text { mesa-po } & \text { chijakta- } k \\ \text { 2SG:NOM } & \text { coffee-ACC } & \text { table-LOC } & \text { sprinkle-PASTP }\end{array}$

'You sprinkled the coffee on the table'.

(5b) $E m_{1}$

$\begin{array}{llll}\text { Empo } & \text { kafe-ae } & \text { mesa-ta } & \text { chijakta-k. } \\ \text { 2SG:NOM } & \text { coffee-INST } & \text { table-ACC } & \text { sprinkle-PASTP }\end{array}$

'You sprinkled the table with coffee'.

The object arguments of these three types of verbs differ in their ability to function as the subject in a passive construction. When the passive suffix - wa is added to a monotransitive verb taking an accusative NP like jamta 'break' $(6 a)$, the theme/patient functions as the passive subject (6b).

(6a) $U$ Peo- $\emptyset \quad$ sota'i-ta jamta-k.

the Peter-NOM pot-ACC break-PASTP

'Peter broke the pot'.

(6b) Soto'i- $\emptyset$ jamta-wa-k.

pot-NOM break-PASS-PASTP

'The pot was broken'.

When - $w a$ is added to a verb like nenka 'sell', which takes an accusative and a postpositional argument, it is the theme that acts as the passive subject (7a). When - wa is added to a verb like miika 'give', which takes two accusative arguments, it is the RECIPIENT that serves as the passive subject (7b).

(7a) $U$ toto' $i-\emptyset$ Karmen-ta-u nenka-wa-k.

the hen-NOM Carmen-ACC-DIR sell-PASS-PASTP

'The hen was sold to Carmen'.

$\left(7 a^{\prime}\right) *$ Karmen $u$-ka toto' $i$-ta nenka-wa-k.

'Carmen was sold the hen'.

(7b) Karmen- $\emptyset \quad$ toto'i-ta miika-wa-k.

Carmen-NOM hen-ACC give-PASS-PASTP

'Carmen was given the hen'.

$\left(7 b^{\prime}\right) * U$ toto' $i-\emptyset$ Karmen-ta miika-wa-k.

'The hen was given [to] Carmen'.

For the third type, there are two possible passive versions. For the active clause in $(5 a)$, the theme serves as the passive subject in $(8 a)$; for the active clause in $(5 b)$, it is the location, as shown in $(8 b)$. 
(8a) $U$ kafe- $\emptyset \quad$ mesa-po chijakta-wa-k. the coffee-NOM table-LOC sprinkle-PASS-PASTP

'The coffee was sprinkled on the table'.

(8b)
$\begin{array}{llll}U & \text { mesa- } \emptyset & \text { kafe-ae } & \text { chijakta-wa-k. } \\ \text { the } & \text { table-NOM } & \text { coffee-INST } & \text { sprinkle-PASS-PASTP }\end{array}$

'The table was sprinkled with coffee'.

With give-type verbs, the RECIPIENT behaves like the theme/patient of a monotransitive verb. Dryer (1986) notes that some languages are sensitive to a distinction between Direct and Indirect Objects, while others are sensitive to a distinction between Primary and Secondary Objects. A Primary Object is a RECIPIENT in a ditransitive clause or the theme/patient in a monotransitive clause, while a Secondary Object is a theme in a ditransitive clause. There are languages which have only the first possibility, some which have only the second, and some which have both. Based on the pattern in which the RECIPIENT is treated grammatically the same as the single object of a monotransitive verb ( $4 b$ and $7 b$ ), it has been suggested that Yaqui is a Primary Object language (Rude 1996). Something similar has been suggested for other Southern Uto-Aztecan languages, i.e., Huichol (Comrie 1982), Cora (Vázquez 1996), and Pima Bajo (Estrada 2003). But using the same criteria and based on constructions like those in $(4 a)$ and $(7 a 0$, Yaqui could be also considered a Direct-Indirect Object language. There is also the third pattern showing the same variable coding as English load in (3). Yaqui is especially interesting in that double and even triple accusative constructions are common, as shown in (9). The question here is which one of those accusative arguments is the primary object; the only possible passive variant of each is given with them.

(9a) Aurelia- $\emptyset \quad$ Ivan-ta mo'obei-ta jinu-ria-k.

Aurelia-NOM Ivan-ACC hat-ACC buy-APL-PASTP

'Aurelia bought Ivan a hat'.

(9a) Ivan- $\emptyset \quad$ mo'obei-ta jinu-ria-wa-k.

Ivan-NOM hat-ACC buy-APL-PASS-PASTP

'Ivan was bought a hat'.

(9b) Goyo- $\emptyset$ ili usi-ta mansana-ta yoem-ta

Goyo-NOM little child-ACC apple-ACC man-ACC

mik-tua-k.

give-CAUSE-PASTP

'Goyo made the child give the man an apple'. 


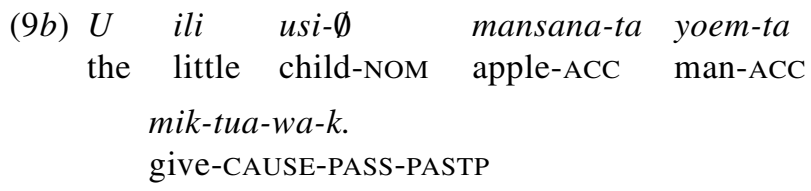

'The child was made to give the man an apple'.
(9c) Goyo- $\emptyset \quad$ Peo-ta jamut-ta toto'i-ta
Goyo-NOM Peter-ACC woman-ACC hen-ACC

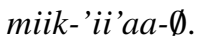
give-WANT-PRES

'Goyo wants Peter to give the woman the hen'.

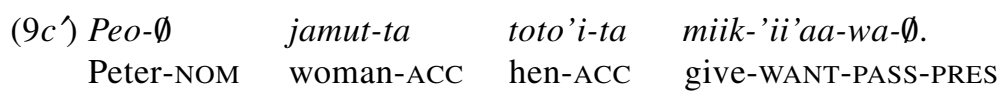

'Peter was wanted to give the woman the hen'.

These derived constructions follow the primary object pattern. Given that there are three accusative NPs in each clause, what determines which one functions as the main "object" of the verb?

This paper analyzes the three classes of multiple "object" constructions in Yaqui: verbs which take three direct NPs, verbs which take an accusative NP plus a PP complement, and derived complex constructions, i.e., applicative, causative, and other valence-increasing forms. The paper has two main goals. The first is to describe the morphosyntactic properties of the nonactor core arguments in these multiple-object constructions and the second is to evaluate the Role and Reference Grammar (Van Valin and LaPolla 1997; henceforth VV\&LP) analysis of "object" selection with these different types of verbs. We show that the analysis of the primary object pattern presented in VV\&LP cannot account for the Yaqui data and, consequently, a new analysis of the phenomena in (4)-(8) is developed. Role and Reference Grammar is briefly introduced in $\mathbf{2}$. We analyze three-argument verbs and propose a revised principle for "object" selection in 3. In $\mathbf{4}$ we discuss several types of derived complex constructions, while $\mathbf{5}$ contains a summary of the paper.

2. Role and Reference Grammar (RRG). This theory posits only one level of syntactic representation and does not make use of traditional grammatical relations. There is a direct mapping between the syntactic and semantic representations of a sentence. Within the syntactic structure, a clause is conceived of as a layered structure of grammatical units. The essential components are $(i)$ the NUCLEUS, containing the verb or other predicating element; (ii) the CORE, consisting of the nucleus and one or more (direct or oblique) core arguments, depending on the valence of the verb; (iii) the PERIPHERY, containing the adjuncts; and (iv) the CLAUSE, which consists of the core and pe- 
ripheral units. In this paper, we focus entirely on core arguments, i.e., the semantic arguments of the verb, regardless of whether they are obligatory or optional. The semantic representation of verbs is grounded in Aktionsart distinctions which are based on the inherent temporal properties of verbs (Vendler 1967). There are four basic classes_-states, achievements, accomplishments, and activities - which are augmented by a fifth class, active accomplishments, and by the causative version of each class. Morphosyntactic tests to determine the class of a verb are given in VV\&LP:91-102. This system of lexical representation is presented in (10). ${ }^{6}$

(10) Lexical representation for Aktionsart classes (VV\&LP:109)

\begin{tabular}{|c|c|}
\hline Verb Class & Logical Structure \\
\hline State & $\overline{\text { pred }^{\prime}(\mathrm{x}) \text { or }(\mathrm{x}, \mathrm{y})}$ \\
\hline Activity & do $^{\prime}\left(\mathrm{x},\left[\operatorname{pred}^{\prime}(\mathrm{x})\right.\right.$ or $\left.\left.(\mathrm{x}, \mathrm{y})\right]\right)$ \\
\hline Achievement & $\begin{array}{l}\text { INGR pred' }(x) \text { or }(x, y) \text { or } \\
\text { INGR } \text { do }^{\prime}\left(x,\left[\operatorname{pred}^{\prime}(x) \text { or }(x, y)\right]\right)\end{array}$ \\
\hline Accomplishment & $\begin{array}{l}\text { BECOME pred }(x) \text { or }(x, y) \text { or } \\
\text { BECOME do }\left(x,\left[\text { pred }^{\prime}(x) \text { or }(x, y)\right]\right)\end{array}$ \\
\hline Active Accomplishment & $\begin{array}{l}\text { do }^{\prime}\left(\mathrm{x},\left[\text { pred }_{1}^{\prime}(\mathrm{x},(\mathrm{y}))\right]\right) \& \text { BECOME } \\
\text { pred }_{2}^{\prime}(\mathrm{z}, \mathrm{x}) \text { or }(\mathrm{y})\end{array}$ \\
\hline Causative & $\begin{array}{l}\alpha \operatorname{CAUSE} \beta \text {, where } \alpha, \beta \text { are LSs of any } \\
\text { type }\end{array}$ \\
\hline
\end{tabular}

The lexical representation of a predicate is termed its Logical Structure (LS), and the semantic interpretation of an argument is a function of its position in this LS. Because the abstract predicates in the system of lexical decomposition can have only zero, one, or two arguments, three-argument verbs must have a complex LS composed of at least two abstract predicates. The general representation for such a predicate is given in (11), with examples in (12). ${ }^{7}$

(11) $\left[\mathbf{d o}^{\prime}(\mathrm{x}, \emptyset)\right]$ CAUSE [BECOME pred' $\left.(\mathrm{y}, \mathrm{z})\right]$

(12) Logical Structure of three-place predicates:

$\begin{array}{ll}\begin{array}{l}\text { give, present } \\ \text { show }\end{array} & \left.\left[\mathbf{d o}^{\prime}(\mathrm{x}, \emptyset)\right] \text { CAUSE [BECOME have' }(\mathrm{y}, \mathrm{z})\right] \\ \text { put } & \left.\left[\mathbf{d o}^{\prime}(\mathrm{x}, \emptyset)\right] \text { CAUSE [BECOME } \mathbf{s e e}^{\prime}(\mathrm{y}, \mathrm{z})\right] \\ \text { load } & \left.\left[\mathbf{d o}^{\prime}(\mathrm{x}, \emptyset)\right] \text { CAUSE [BECOME be-LOC' }(\mathrm{y}, \mathrm{z})\right] \\ & \left.\left[\mathbf{d o}^{\prime}(\mathrm{x}, \emptyset)\right] \text { CAUSE [BECOME be-on' }(\mathrm{y}, \mathrm{z})\right]\end{array}$

\footnotetext{
${ }^{6}$ In this system of lexical decomposition, state predicates are represented simply as pred and activity predicates contain $\mathbf{d o}^{\prime}$; accomplishment LSs, which are durative, contain BECOME and achievements LSs, which are punctual, contain INGR 'ingressive'.

${ }^{7}$ When the nature of the cause is unspecified, e.g., Mary open the door vs. Mary pushed open the door, the unspecified activity is represented in the LS by $\emptyset$, as in ' $\mathbf{d o}^{\prime}$ ' $\left.\mathrm{x}, \emptyset\right) \ldots$.
} 


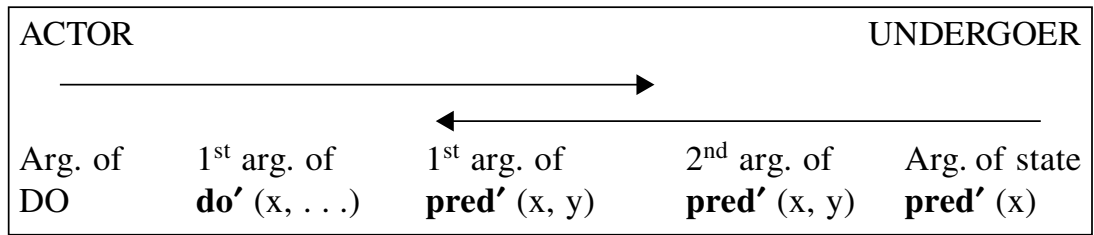

FIG. 1.-The Actor-Undergoer Hierarchy. $\rightarrow=$ increasing markedness of realization of argument as macrorole.

RRG recognizes two types of semantic relations: (a) traditional thematic roles—agent, effector, patient, theme, goal, recipient, source—which are used only as mnemonics for the LS argument positions, and (b) semantic macroroles-actor and undergoer-which are generalizations across the argument types of particular verbs that have significant grammatical consequences. Actor and undergoer correspond to the two primary arguments of a transitive predication, either one of which may be the single argument of an intransitive verb, depending on its semantics; e.g., with run (activity), the single argument is an actor and with die (accomplishment), it is an undergoer. They are macroroles, or generalized semantic roles, because they each subsume a number of traditional thematic relations. With a verb like murder, the actor is an agent and the undergoer a patient; with a verb like see, the actor is an experiencer and the undergoer a stimulus; with a verb like put, the actor is an effector and the undergoer is a theme. ${ }^{8}$ Actor is not equivalent to syntactic subject, nor is undergoer equivalent to syntactic object. This is clear in an English passive clause where the undergoer is the subject and the actor, if it occurs, is an adjunct PP, e.g., the sandwich was eaten by the boy.

Generally speaking, the most agent-like argument is the actor, the most patient-like is the undergoer. In order to determine the semantic macroroles with a particular verb, the theory proposes the Actor-Undergoer Hierarchy shown in figure 1. In a LS with two arguments, the highest (leftmost) argument will be the actor and the lowest (rightmost) the undergoer.

With a causative LS representation like (11), the lowest argument $z$ is only the default choice for undergoer in a language like English, meaning that it is possible for the $y$ argument to be selected as the undergoer. This alternation in undergoer selection is shown for the verb give in (13). The first argument of do' is Goyo (x); the RECIPIENT Aurelia (y) is the first argument in

\footnotetext{
${ }^{8}$ Agents and Effector thematic relations are distinguished. For verbs that demand a human agent, such as murder, the representation of ' $\mathrm{DO}\left(\mathrm{x},\left[\mathbf{d o}^{\prime}\right.\right.$ ( $\mathrm{x}, \ldots$.' is used, whereas for verbs that allow inanimate entities, such as kill, just $\mathbf{d o}^{\prime}(\mathrm{x}, \ldots)$ ' is used, i.e., Malaria kills/*murders people. Hence, DO appears only in the LS of those verbs which lexicalize agency. Animate and human effectors may be construed as agents (Holisky 1987 and Van Valin and Wilkins 1996).
} 
the second component BECOME have' (y, z), while the theme flowers (z) is the second argument in it.

(13a) [do' (Goyo, Ø)] CAUSE [BECOME have' (Aurelia, flowers)]

(13b) Goyo ${ }_{[\mathrm{A}]}$ gave the flowers ${ }_{[\mathrm{U}]}$ to Aurelia unmarked choice

(13c) Goyo $_{[\mathrm{A}]}$ gave Aurelia $_{[\mathrm{U}]}$ the flowers marked choice

According to the Actor-Undergoer Hierarchy (AUH), the highest argument $x$ in the LS in (13a) is selected as the actor (Goyo) and the lowest argument $z$ as the undergoer (flowers); because the clause is in active voice, the actor appears in the core-initial position. The $y$ argument (Aurelia) is a non-macrorole core argument, marked by a preposition. This yields (13b). Because the flowers and Aurelia appear in the LS for give, they are both core arguments of give in (13b); the former is a direct core argument, while $\mathrm{Au}$ relia is an oblique core argument marked by to. In terms of the AUH, (13b) shows the unmarked choice for undergoer, since the undergoer corresponds to the second argument of have' $(\mathrm{y}, \mathrm{z})$, the lowest ranking argument in the LS. In (13c), the actor selection is the same but the undergoer selection is different: the $y$ argument (Aurelia) is chosen as the undergoer, leaving flowers as a non-macrorole direct core argument. Here, both Aurelia and the flowers are direct core arguments. The undergoer does not correspond to the second argument of have' $(\mathrm{y}, \mathrm{z})$ but to the $y$ argument, the first argument, and, therefore, the clause in (13c) shows a marked undergoer selection in terms of the AUH, because the $y$ argument is not the lowest ranking argument in the LS.

Another important feature of RRG is that the traditional grammatical relations of subject, direct object, and indirect objects have no theoretical status. Instead of the traditional "subject," the concept of Privileged Syntactic Argument (PSA) is used. The PSA is selected on the basis of the hierarchy in (14). For an accusative construction, the kind found in English and Yaqui, the PSA corresponds to the highest ranking direct core argument in terms of the PSA hierarchy. The notion of undergoer and core argument accounts for direct and indirect objects.

(14) Privileged Syntactic Argument Selection Hierarchy (PSA)

Arg. of DO $>1^{\text {sr }} \arg$. of $\mathbf{d o}^{\prime}>1^{\text {st }} \arg$. of pred' $(x, y)>2^{\text {nd }} \arg$. of $\operatorname{pred}^{\prime}(x, y)>A r g$. of pred' $(x)$

In both English and Yaqui, the default choice for PSA (subject) is the actor argument, while in a passive construction, the undergoer is the PSA.

\section{Properties of two- and three-argument verbs in Yaqui.}

3.1. Two-argument verbs. Yaqui is primarily a verb-final language with a relatively free word order among the constituents, where case marking 
serves to identify the grammatical relation of the arguments. Usually, the subject NP comes first, followed by the object NPs, as in (15a); but if the subject appears as a bound pronoun, it occupies the second position in the clause, as in (15b). Yaqui nominative case is unmarked, while the accusative is indicated by the suffix -ta; pronouns have distinctive nominative and accusative forms.

\begin{tabular}{|c|c|c|c|}
\hline$(15 a)$ & $\begin{array}{l}\text { Етро } \\
\text { 2sG:NOM }\end{array}$ & $\begin{array}{l}\text { Peo-ta } \\
\text { Peter-ACC }\end{array}$ & $\begin{array}{l}\text { bicha-k. } \\
\text { see-PASTP }\end{array}$ \\
\hline & 'You saw P & 'eter'. & \\
\hline $5 b)$ & $\begin{array}{l}\text { Peo-ta='e } \\
\text { Peter-ACC }=\end{array}$ & $2 \mathrm{SG}: \mathrm{NOM}$ & $\begin{array}{l}\text { bicha-k. } \\
\text { see-PASTP }\end{array}$ \\
\hline & 'You saw P & 'eter'. & \\
\hline $5 c)$ & $\begin{array}{l}\text { Peo- } \emptyset \\
\text { Peter-NOM }\end{array}$ & $\begin{array}{l}\text { enchi } \\
\text { 2sG:ACC }\end{array}$ & $\begin{array}{l}\text { bicha-k. } \\
\text { see-PASTI }\end{array}$ \\
\hline
\end{tabular}

As in other Uto-Aztecan languages, plural and accusative marking on nouns are mutually exclusive (Lindenfeld 1973). ${ }^{9}$ Compare (16a) and (16b). Clauses in which the two core arguments are plural (16c) are ambiguous, although the preferred reading is where the nominal actor precedes the nominal undergoer.

\begin{tabular}{|c|c|c|c|c|}
\hline$(16 a)$ & $\begin{array}{ll}U & \text { goi- } \emptyset \\
\text { the } & \text { coyote-NOM }\end{array}$ & $\begin{array}{l}u-k a \\
\text { the-ACC }\end{array}$ & $\begin{array}{l}\text { chu'u-ta } \\
\text { dog-ACC }\end{array}$ & $\begin{array}{l}k e^{\prime} e-k a . \\
\text { bite-PASTP }\end{array}$ \\
\hline & \multicolumn{4}{|c|}{ 'The coyote bit the dog'. } \\
\hline$(16 b)$ & $\begin{array}{ll}U & g o i-\emptyset \\
\text { the } & \text { coyote-NOM }\end{array}$ & $\begin{array}{l}u-m e \\
\text { the-PL }\end{array}$ & $\begin{array}{l}\text { chu'u-im } \\
\text { dog-PL }\end{array}$ & $\begin{array}{l}k e^{\prime} e-k a . \\
\text { bite-PASTP }\end{array}$ \\
\hline & \multicolumn{4}{|c|}{ 'The coyote bit the dogs'. } \\
\hline $6 c)$ & $\begin{array}{ll}U-m e & \text { goi-m } \\
\text { the-PL } & \text { coyote-PL }\end{array}$ & $\begin{array}{l}u-m e \\
\text { the-PL }\end{array}$ & $\begin{array}{l}\text { chu'u-im } \\
\text { dog-PL }\end{array}$ & $\begin{array}{l}k e^{\prime} e-k a . \\
\text { bite-PASTP }\end{array}$ \\
\hline
\end{tabular}

\footnotetext{
${ }^{9}$ The accusative and plural co-occur only in the pronoun am '3PL:ACC'. This complementary distribution is also observed when nouns function as the complement of a postposition, e.g., jaтисhi-me-u 'to the women'. This complementarity is presumably an instance of morphological blocking and does not appear to have any syntactic consequences. Escalante (1990) argues for a reanalysis of -tau as a dative case marker, but forms like jamuchi-me- $u$ would appear to be problematic for such an account.
} 
$\begin{array}{cllll}\text { (16d) } \begin{array}{l}\text { U-me } \\ \text { the-PL }\end{array} & \text { chu'u-im } & \text { u-me } & \text { goi-m } m & k e ' e-k a . \\ \text { the-PL } & \text { coyote-PL } & \text { bite-PASTP }\end{array}$

'The dogs bit the coyotes'.

This language shows a rich system of postpositions, which semantically encode a wide range of spatial, temporal, and associative meanings (Dedrick and Casad 1999). In (17a) and (17b), the directional $-u$ and the comitative -mak are illustrated; the occurrence of the suffix - $t a$ is governed by the postpositions. Other postpositions, such as the locative -po in (17c), take a bare complement.

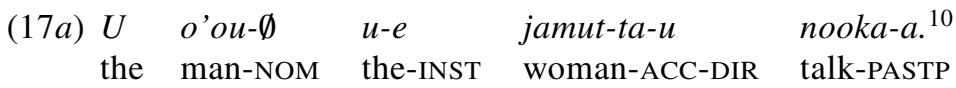

'The man talked to the woman'.

(17b) $A p r$

$\begin{array}{llll}\text { Apa-ta-mak } & \text { yebij-ne } & \text { in } & \text { maala. } \\ \text { father-ACC-COM } & \text { arrive-EXPECT } & \text { 1SG:POSS } & \text { mother }\end{array}$

'My mother will arrive with my grandfather'.

(17c) Goyo- $\emptyset$ mesa-po naaso-ta yecha-k.

Goyo-NOM table-LOC orange-ACC put-PASTP

'Goyo put the orange on the table'.

With monotransitive verbs, there are two core arguments. When the passive suffix - $w a$ is added to verbs taking an accusative NP, such as ke'e 'bite' in (16a), the actor NP is omitted and the undergoer acts as the passive PSA, as shown in $(18 a)$. When $-w a$ is added to verbs taking a postpositional argument, such as nooka 'talk to' in (17a), the postpositional argument remains as a non-PSA argument and the clause is interpreted as an impersonal sentence $(18 b) .{ }^{11}$

(18a) $U$ chu'u- $\emptyset \quad k i^{\prime} i-w a-k$.

the dog-NOM bite-PASS-PASTP

'The dog was bitten'.

(18b)
Jamut-ta-u
nooka-wa-k.
woman-ACC-DIR
talk-PASS-PASTP

'Someone talked to the woman' / *'The woman was talked to'.

\footnotetext{
${ }^{10}$ Determiners are also morphologically marked in Yaqui. When the NP is accusative, the determiners take the suffix $-k a$; when the NP is an object of postposition, they are marked by -e (instrumental?).

${ }^{11}$ A reviewer rightly comments that postpositional arguments are not required in Yaqui impersonal sentences; e.g., nooka-wa-k 'there was talking' can be a sentence on its own.
} 
TABLE 1

Three-Argument Verbs in Yaqui

\begin{tabular}{|c|c|c|c|c|c|}
\hline \multicolumn{2}{|c|}{ Type A } & \multicolumn{2}{|r|}{ Type B } & \multicolumn{2}{|r|}{ Type C } \\
\hline nenka & 'sell' & miika & 'give' & chijakta & 'splash, sprinkle' \\
\hline jinu & 'buy' & maka & 'present as a gift' & benta & 'spread' \\
\hline mana & 'serve, offer' & bittua & 'show' & seaji'iki & 'embroider' \\
\hline bittua & 'send' & u'ura & 'take away' & jissa & 'spray' \\
\hline reuwe & 'borrow' & reuwa & 'lend' & & \\
\hline bwise & 'pass' & majta & 'teach' & & \\
\hline aawa & 'request' & tejwa & 'tell' & & \\
\hline mabeta & 'receive' & & & & \\
\hline teuwa & 'tell to' & & & & \\
\hline toja & 'bring' & & & & \\
\hline nattemae & 'ask' & & & & \\
\hline
\end{tabular}

In terms of RRG, this situation is explained as follows. With a monotransitive verb, the nominative NP is the actor and the accusative NP is the undergoer. NPs marked by postpositions are non-macrorole core arguments and cannot act as the passive PSA. Consequently, $u$-ka chu'u-ta 'the dog' $(18 a)$ is an undergoer direct core argument, while jamut-ta- $u$ 'to the woman' $(18 b)$ is a non-macrorole oblique core argument. Only the undergoer acts as the PSA in a passive construction and, therefore, only 'dog' not 'woman' can function as the passive PSA.

RRG case assignment rules for Yaqui are given in (19); they apply to direct core arguments only. Yaqui has only two direct cases, nominative and accusative.

(19) Case assignment rules for Yaqui:

Assign nominative case to the highest ranking macrorole.

Assign accusative case to the other direct core arguments.

Oblique core arguments are marked by postpositions such as the directional $-u$, the instrumental $-e$, the locatives -po, $-t$. In this paper, we assume that postpositions are assigned lexically by the verb.

3.2. Three-argument verbs. There are three types of verbs which take three core arguments. The first group, Type A, takes an accusative NP and a PP as core arguments. The second group, Type B, takes two accusative core arguments, the RECIPIENT and the theme. The third group, Type $\mathrm{C}$, takes two arguments with variable coding in which either the theme is marked accusative and the other as a locative PP, or the location appears as an accusative $\mathrm{NP}$ and the theme as an instrumental PP. See table 1.

For Type A, just the accusative theme is obligatory, while the postpositional arguments are optional; all these verbs lack a double-object variant. 
Hence the accusative theme is a direct core argument, whereas the RECIPIENT is an oblique core argument. In (20), the verb nenka 'sell' is illustrated; the lexical representation for nenka in (20a) is presented in $(20 d)$.
(20a) Goyo- $\emptyset$
Lupe-ta- $u$
toto' $i$-ta nenka-k.
Goyo-NOM
Lupe-ACC-DIR
hen-ACC sell-PASTP

'Goyo sold the hen to Lupe'.

(20b)
Goyo- $\emptyset$
$u-k a$
toto' $i$-ta
nenka-k.
Goyo-NOM the-ACC hen-ACC sell-PASTP

'Goyo sold the hen'.

(20c) *Goyo- $\emptyset$ Lupe-ta-u nenka-k.

'Goyo sold to Lupe'.

$(20 d)$ [do' (Goyo-, Ø)] CAUSE [BECOME have' (Lupe-, toto' $i-$-)]

More examples are shown below. The postpositional argument marked by the directional $-u$ may indicate the goal in (21a) and the source in (21b); the locative -betana 'from' indicates the source (21c).
) Armando- $\emptyset$
seewa-m
teopo- $u$
toi-ne.
Armando-NOM flower-PL church-DIR bring-EXPECT

'Armando will bring flowers to the church'.

$\begin{array}{rllll}\text { (21b) Aurelia- } \emptyset & \text { koari-m jita } & \text { nenki-reo-ta- } u & \text { jinu- } \emptyset . \\ \text { Aurelia-NOM } & \text { skirt-PL } & \text { thing } & \text { sell-er-ACC-DIR } & \text { buy-PRES }\end{array}$

'Aurelia is buying skirts from the seller'.

(21c)
$\begin{array}{llll}\text { Beti- } \emptyset & u-k a & b w a ' a-m-t a & m a b e t a-k \\ \text { Beti-NOM } & \text { the-ACC } & \text { eat-REL-ACC } & \text { receive-PASTP }\end{array}$
kobanao-ta-betana. governor-ACC-from

'Beti received the food from the governor'.

Most verbs of saying are classified in this group. The examples in (22) show that the "content of speaking" appears as accusative, while the RECIPIENT, in this case an addressee, appears as a directional argument.
(22a)
Aurelia- $\emptyset$
o'ou-ta-u
ta'e-m nattemae- $k$.
Aurelia-NOM
name-PL ask-PASTP
man-ACC-DIR
'Aurelia asked the names from the man'.
Maria- $\emptyset$
Karmen-ta-u
ji-ta
teuwa-k.
Maria-NOM
Carmen-ACC-DIR thing-ACC
tell to-PASTP
'Maria told something to Carmen'. 
$(22 c)$
Peo- $\emptyset$
Lupe-ta- $u$
tomi-ta
aawa-k.
Peter-NOM
Lupe-ACC-DIR
money-ACC
request-PASTP
'Peter requested money from Lupe'.

For Type B verbs, both -ta marked arguments are obligatory, meaning that the absence of one results in ungrammaticality. In (23), the verb miika 'give' is illustrated; the lexical representation for miika in $(23 a)$ is presented in $(23 d)$.

(23a)

Goyo-NOM Lupe-ACC hen-ACC give-PASTP

'Goyo gave Lupe the hen'.

(23b) *Goyo- $\emptyset u$-ka toto' $i$-ta miika-k.

'Goyo gave the hen'.

(23c) *Goyo- $\emptyset$ Lupe-ta miika-k.

'Goyo gave Lupe'.

(23d) [do' (Goyo-, Ø)] CAUSE [BECOME have' (Lupe-, toto' $i-$-)]

Verbs in this group express a causing event where one person (actor) causes the other animate participant (RECIPIENT) to have or know something (theme), or not to have something, as with u'ura 'take away' in (24c).

(24b) Aurelia- $\emptyset \quad$ Jorge-ta kuenta-m majta-ne.

Aurelia-NOM Jorge-ACC sum-PL teach-EXPECT

'Aurelia will teach Jorge the sums'.

(24b)
Maria- $\emptyset$
Karmen-ta ji-ta
tejwa-k.
Maria-NOM
Carmen-ACC
thing-ACC
tell-PASTP

'Maria told Carmen something'.
(24c) $U$ ili uusi- $\emptyset$ Lupe-ta tomi-ta
the little child-NOM Lupe-ACC money-ACC
u'ura-k.
take.away-PASTP

'The little child took the money away [from] Lupe'.

There is another characteristic that distinguishes Type A and Type B verbs, whether the transfer is completed or not (Koenig and Davis 2001 and Levin and Rappaport-Hovav 2002). The idea is that the expression of RECIPIENT as an accusative NP generates a successful transfer implicature, while expression of RECIPIENT as a PP may generate an implicature of nonsuccess. Yaqui Type A verbs do not necessarily imply a successful transfer, as shown 
in (25a), whereas Type B verbs do imply that the transfer was actually achieved, as shown in the ungrammaticality of $(25 b)$.

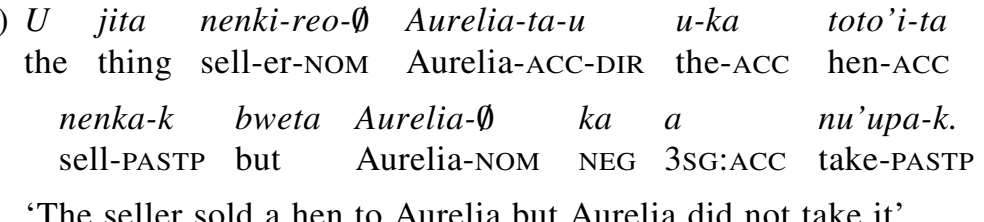

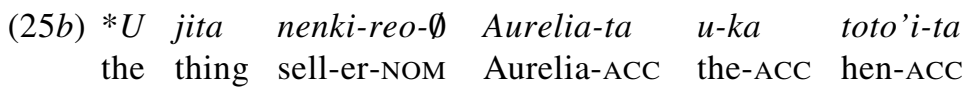
$\begin{array}{llllll}\text { miika- } k & \text { bweta } & \text { Aurelia- } \emptyset & k a & a & n \text { n'upa- }^{\prime} . \\ \text { give-PASTP } & \text { but } & \text { Aurelia-NOM } & \text { NEG } & \text { 3SG:ACC } & \text { take-PASTP }\end{array}$

'The seller gave Aurelia a hen but Aurelia did not take it'.

Bit-tua 'see-CAUSE' appears to be the only verb that expresses both variants: the PP variant meaning 'send' (26a) and the double accusative variant meaning 'show' (26b).

(26a) Aurelia- $\emptyset \quad$ Karmen-ta-u toto'i-ta bit-tua-k. Aurelia-NOM Carmen-ACC hen-ACC see-PASTP

'Aurelia sent the hen to Carmen'.
(26b) Aurelia- $\emptyset \quad$ Karmen-ta toto'i-ta bit-tua-k.
Aurelia-NOM Carmen-ACC hen-ACC see-CAUSE-PASTP
'Aurelia showed Carmen the hen'.

However, Type $\mathrm{C}$ verbs do permit variable object coding. One variant codes the theme as accusative and the location as a locative PP, whereas the other variant codes the location as accusative and the theme as an instrumental PP. Although not necessarily ungrammatical, the omission of one of the two nonactor core arguments is odd. The verb chijakta 'sprinkle' was exemplified in (5). Another example is the verb benta 'spread'.

(27a) Goyo- $\emptyset$ pannim-me-t mantekia-ta benta-k.

Goyo-NOM bread-PL-LOC butter-ACC spread-PASTP

'Goyo spread the butter on the breads'.

(27b) Goyo- $\emptyset \quad$ panni-m mantekia-e benta-k.

Goyo-NOM bread-PL butter-INST spread-PASTP

'Goyo spread the breads with butter'.

Note that for the variant in $(27 a)$, the theme mantekia 'butter' is accusative, while the location is marked by the postposition $-t$ 'on'. For the variant 
in $(27 b)$, the theme is introduced by the postposition -(a)e 'with', whereas the location is coded as an (accusative) plural argument.

The analysis of multiple-object constructions in Yaqui requires the use of morphosyntactic tests to ascertain whether the nonactor core arguments are equivalent syntactically. Rude (1996) investigates cliticization, right dislocation, reflexivization, relativization, adjective marking, and passive voice processes, arguing that, except for passivization, the two nonactor core arguments have access to all of these functions. Among the multiple nonactor core arguments, only the undergoer may serve as the PSA of a passive construction. Of the two logically possible passive versions, only one is grammatical. For Type A verbs, only the theme can serve as the passive PSA; hence it is the undergoer.

(28a) Goyo- $\emptyset \quad$ Lupe-ta-u toto'i-ta nenka-k.

Goyo-NOM Lupe-ACC-DIR hen-ACC sell-PASTP

'Goyo sold the hen to Lupe'.

(28b) $U$ toto'i- $\emptyset$ Lupe-ta-u nenka-wa-k.

the hen-NOM Lupe-ACC-DIR sell-PASS-PASTP

'The hen was sold to Lupe'.

(28c) *Lupe- $\emptyset$ toto'i-ta nenka-wa-k.

'Lupe was sold to the hen'.

(28d) [do' (Goyo-, Ø)] CAUSE [BECOME have' (Lupe-, toto' $i-$-)]

With Type A verbs, the highest ranking argument in the LS is selected as actor (Goyo); the theme is the lowest argument and so it is selected as the undergoer. The RECIPIENT appears as a non-macrorole oblique core argument. Following the case assignment rules for Yaqui in (19), the highest ranking macrorole, the actor Goyo, will be assigned nominative case, and the other direct core argument, the undergoer toto' $i$, will be assigned accusative. This verb assigns the postposition $-u$ to its non-macrorole argument, which yields $(28 a)$. In the passive, however, the actor is suppressed, leaving the undergoer as the highest ranking direct core argument; hence it receives nominative case, as in (28b). This resembles the "unmarked" choice for undergoer in languages like English since the undergoer is the second argument of have' (y, z), the lowest ranking argument in the LS in (28d).

On the other hand, for Type B verbs, it is the accusative RECIPIENT that acts as the passive PSA, as shown in (29b). Hence, it is the undergoer. The theme appears as a non-macrorole direct core argument in the accusative case. 
(29a) Goyo- $\emptyset \quad$ Lupe-ta toto'i-ta miika-k.

Goyo-NOM Lupe-ACC hen-ACC give-PASTP

'Goyo gave Lupe the hen'.

(29b) Lupe- $\emptyset \quad u-k a \quad$ toto'i-ta miik-wa-k.

Lupe-NOM the-ACC hen-ACC give-PASS-PASTP

'Lupe was given the hen'.

(29c) *U toto' $i-\emptyset$ Lupe-ta miik-wa-k.

'The hen was given [to] Lupe'.

(29d) [do' (Goyo-, Ø)] CAUSE [BECOME have' (Lupe-, toto' $i-)$ ]

With respect to the LS in $(29 d)$, the highest ranking argument is the actor, but the selection for undergoer is different from that in (28): rather than the lowest ranking argument being selected, the second highest, Lupe, is selected as the undergoer. This choice is not reflected in the case marking, because all of the nonactor direct core arguments are accusative in Yaqui. It is only apparent in the passive construction: only the accusative RECIPIENT can act as the passive PSA. Following the case assignment rules for Yaqui, in $(29 b)$ the highest ranking macrorole receives nominative case, and because the actor is suppressed, the undergoer receives the nominative case; hence Lupe is the undergoer. In languages like English, the selection of the RECIPIENT over the theme as the undergoer is the "marked" choice, because the RECIPIENT is not the lowest ranking argument in the LS in (29d).

For Type $\mathrm{C}$ verbs, either of the two nonactor core arguments can show object properties. When - $w a$ is added to the active variant taking a locativemarked NP, as in (27a), the accusative theme acts as passive PSA. Hence, it is the undergoer.

(30a) $U$ mantekia- $\emptyset$ pannim-me-t benta-wa-k. the butter-NOM bread-PL-LOC spread-PASS-PASTPFL

'The butter was spread on the breads'.

$\left(30 a^{\prime}\right) * U-m e$ panni-m mantekia-ta benta-wa-k.

'The breads were spread butter'.

When - $w a$ is added to the active variant taking an instrumental-marked $\mathrm{NP}$, as in $(27 b)$, the accusative location functions as the passive PSA. Hence, it is the undergoer.

(31a) U-me panni-m mantekia-e benta-wa-k. the-PL bread-NOM butter-INST spread-PASS-PASTP

'The breads were spread with butter'. 


\section{$\left(31 a^{\prime}\right) * U$ mantekia- $\emptyset$ panni-m benta-wa-k.}

'The butter was spread breads'.

There is another difference among the three verb types. Whereas Type A and Type $\mathrm{C}$ verbs allow the third argument to be inanimate, Type $\mathrm{B}$ verbs, with one exception, require an animate RECIPIENT. The exception is u'ura 'take away' (see 32).

RRG recognizes that the primary object pattern is different from the directindirect object pattern because it realizes the "marked" linking possibility in terms of the AUH with Type B verbs like miika 'give'. In order to account for this, VV\&LP:387 propose that undergoer selection is affected by animacy: if there are two nonactor direct core arguments which could be selected and one of them is animate, then the animate will be selected as the undergoer over the inanimate, regardless of its position in the LS. While that accounts for clauses like (23) and (24), for example, constructions like those in (32) are problematic for this analysis: in (32a) theme and RECIPIENT are both inanimate, while in $(32 b)$ they are both human.

(32a) Tibu- $\emptyset \quad u$-ka wikoi-ta juiwa-m u'ura-k.

Tibu-NOM the-ACC rifle-ACC bullet-PL take.away-PASTP

'Tibu emptied the rifle [of] the bullets'.

(32b) Aurelia- $\emptyset \quad$ Karmen-ta u-ka ili usi-ta

Aurelia-Nom Carmen-ACC the-ACC little child-ACC

bit-tua-k.

See-CAUSE-PASTP

'Aurelia showed Carmen the child'.

Since both accusative NPs are inanimate in (32a), the animacy principle makes no predication about which argument is the undergoer. Moreover, the basic undergoer selection embodied in the AUH in figure 1 makes the wrong prediction, as (33) shows.

(33a) *U-me juiwa-m u-ka wikoi-ta u'ura-wa-k. the-PL bullet-PL the-ACC rifle-ACC take.away-PASS-PASTP 'The bullets were taken out [of] the rifle'.

(33b) $U$ wikoi- $\emptyset$ juiwa-m u'ura-wa-k. the rifle-NOM bullet-PL take.away-PASS-PASTP

'The rifle was emptied [of] the bullets'.

The lowest ranking argument in the LS for $u$ 'ura 'take away' would be the theme, juiwa 'bullet', and therefore following the AUH it should be selected as undergoer, yielding the passive construction in (33a). This, however, is 
ungrammatical; only the RECIPIENT wikoi 'rifle' can serve as the passive PSA, indicating that it is the undergoer. Neither the basic undergoer selection principle nor the animacy principle predicts the ungrammaticality of $(33 a)$ and the grammaticality of $(33 b)$.

The situation is slightly different with respect to $(32 b)$, in which both accusative NPs are human. In this case, the animacy principle predicts that either NP can be selected as undergoer and, consequently, it predicts that there should be two possible passive versions of "Aurelia showed Carmen the child' in (32b). These are given in (34).

(34a) Karmen- $\emptyset \quad u$-ka ili usi-ta bit-tua-wa-k. Carmen-NOM the-ACC little child-ACC see-CAUSE-PASS-PASTP 'Carmen was shown the child'.

$$
\begin{aligned}
& U \quad \text { ili usi- } \emptyset \quad \begin{array}{l}
\text { Karmen-ta } \\
\text { the little child-NOM } \text { Carmen-ACC }
\end{array} \text { see-CAUSE-PASS-PASTP } \\
& \text { *'The child was shown [to] Carmen' / 'The child was shown } \\
& \text { Carmen'. }
\end{aligned}
$$

In (34a) the RECIPIENT is selected as undergoer and appears as the passive PSA, while in (34b) the theme is selected as undergoer and so functions as the passive PSA. The problem is that (34b) is not a possible passive version of $(32 b)$ with that meaning. The example with two human accusative NPs is actually ambiguous, as either human NP can be construed as the RECIPIENT. The other possible reading is 'Aurelia showed the child Carmen', where 'the child' is the RECIPIENT; the clause in (34b) is the valid passive version for this reading. Accordingly, there are two LSs for (32b), shown in (35).

(35a) [do' (Aurelia-, Ø)] CAUSE [BECOME see' (Karmen-, usi-)] = 'Aurelia showed Carmen the child'.

(35b) [do' (Aurelia-, Ø)] CAUSE [BECOME see' (usi-, Karmen-)] = 'Aurelia showed the child Carmen'.

Both nonactor human arguments appear in the accusative case, hence the ambiguity. (34a) is the only possible passive of (35a) and (34b) is the only possible passive of $(35 b)$. The animacy principle predicts that there should be two possible passive versions for each LS, which, as we have shown, is incorrect. Hence the animacy principle makes another incorrect prediction: it fails to correctly predict undergoer selection with Type B verbs that take two inanimate arguments and with verbs that take two human arguments.

In sum, we have seen that Yaqui presents three types of three-argument verbs. The first group, Type A, selects the theme as the undergoer, leaving the third argument as a non-macrorole core argument. The second group, Type B, chooses the RECIPIENT as the undergoer, leaving the theme as a 
non-macrorole direct core argument. The third group, Type $\mathrm{C}$, shows variable undergoer selection: for the locative variant, the undergoer is the theme, while for the instrumental variant, the undergoer is the location. Furthermore, we have seen that the undergoer-as-animacy principle proposed by VV\&LP does not predict the actual undergoer choice when the two nonactor core arguments are both animate or inanimate. The question is, how can we explain this mixed system and, most important, how can we determine the actual undergoer selection for each of these types of verbs?

An alternative way of characterizing undergoer selection with Type B verbs is to say that the undergoer is the second highest ranking argument in the LS. Consider the LS for the verb miika 'give', repeated in (36d).

(36a) Goyo- $\emptyset \quad$ Lupe-ta toto'i-ta miika-k.

Goyo-NOM Lupe-ACC hen-ACC give-PASTP

'Goyo gave Lupe the hen'.

(36b) Lupe- $\emptyset \quad u$-ka toto'i-ta miika-wa-k.

Lupe-NOM the-ACC hen-ACC give-PASS-PASTP

'Lupe was given the hen'.

(36c) *U toto' $i-\emptyset$ Lupe-ta miik-wa-k.

'The hen was given Lupe'.

(36d) [do' (Goyo-, Ø)] CAUSE [BECOME have' (Lupe-, toto' $i-)$ ]

According to the AUH given in figure 1, the first argument of $\mathbf{d o}^{\prime}(\mathrm{x}, \ldots)$, Goyo, is the highest ranking argument; the first argument of a two-place

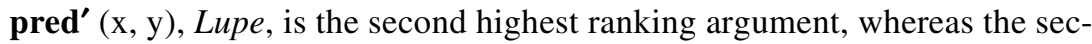
ond argument of such a predicate, toto'i 'hen', is the lowest ranking argument in the LS. As (36b) and (36c) clearly show, it is the NP Lupe, the second highest ranking argument in the LS, that is selected as undergoer.

As an initial hypothesis, let us take this to be the principle for undergoer selection with Type B verbs in Yaqui: the undergoer is the second highest ranking argument in the LS. ${ }^{12}$ An initial test of this would be simple transitive verbs: does it work for them? If we look at the LS for $(6 a)$, repeated below, we can see that it does in fact work for simple transitive verbs as well.

${ }^{12}$ In (36d), Lupe is also the second lowest ranking argument. For this LS, the two formulations are equivalent. However, when we examine derived verbs in $\mathbf{4}$ below, we show that the "second highest ranking argument" analysis is the correct principle. 
$\begin{array}{lll}\text { (37a) Nepo } & \text { Peo-ta } & \text { bicha- } k \text {. } \\ \text { 1sG:NOM } & \text { Peter-ACC } & \text { see-PASTP }\end{array}$

'I saw Peter'.

(37b) see' $^{\prime}(1 \mathrm{sg}$, Peo- $)$

The selection of the actor is unaffected: the highest ranking argument in the LS is the actor, which means that the first-singular argument is the actor; it is realized as nepo. The principle we have proposed states that the second highest ranking argument is the undergoer, which means that Peo is the undergoer. Thus, this revised undergoer selection rule works for simple transitive verbs like bicha 'see' and for three-argument verbs like miika 'give'.

However, Type A verbs like nenka 'sell' do not follow this principle. With these verbs the second highest argument is not selected as the undergoer, the lowest ranking argument is; the second highest ranking argument appears as an oblique argument marked by a postposition. Then, whereas Type A verbs select the lowest ranking argument in the AUH, Type B verbs select the second highest ranking argument. Hence the split between Type A and Type B verbs in Yaqui revolves around different undergoer selection principles: Type A verbs follow the same principle as English, while Type B verbs follow the revised principle for the primary object pattern. In addition, Type $\mathrm{C}$ verbs in Yaqui, like their English counterparts, can select the undergoer like both Type A and Type B verbs.

4. Derived multiple-object constructions. Yaqui has an extensive set of valence-increasing suffixes. Some are common cross-linguistically, such as applicatives and causatives, and some are less common, such as desiderative, reported speech, and propositional attitude. These are investigated here since most of them allow only the multiple accusative variant.

4.1. Applicative clauses. Generally, the term applicative has been used to refer to those clauses that encode a new argument, the beneficiary, as a direct core argument rather than as an oblique or adjunct phrase. For the same LS, English has alternative clauses to refer to this new argument: the "unmarked" choice where the beneficiary for Sue is expressed as an oblique core argument and the theme is selected as the undergoer (38a), and the "marked" choice where Sue is coded as a direct core argument (38b) and hence it is the undergoer. ${ }^{13}$

\footnotetext{
${ }^{13}$ This LS is only for the recipient benefactive reading. Plain and deputative beneficiaries have different LSs. See VV\&LP:382-84 for details on the analysis of purposive constructions.
} 
(38a) Larry baked a cake for Sue

unmarked choice

(38b) Larry baked Sue a cake

marked choice

(38c) $[$ [do' $(\mathrm{x}, \emptyset)]$ CAUSE [BECOME pred' (z)] ] PURP [BECOME have' $\left.^{\prime}(\mathrm{y}, \mathrm{z})\right]$

Yaqui also has two alternative constructions. The new argument can occur as an oblique phrase marked by the postposition betchi'ibo 'for', as in (39b), and as a direct core argument when the verb takes the derivational suffix -ria, as in $(39 c)$. If the basic verb is transitive, as in this case, the applicative derives a double-object construction.

(39a)

$\begin{array}{llll}\text { Aurelia- } \emptyset & u-k a & \text { wakabak-ta } & \text { joa- } k \text {. } \\ \text { Aurelia-NOM } & \text { the-ACC } & \text { wakabaki-ACC } & \text { cook-PASTP }\end{array}$

'Aurelia cooked the wakabaki'.

(39b) Aurelia- $\emptyset \quad u$-ka wakabak-ta joa-k

Aurelia-NOM the-ACC wakabaki-ACC cook-PASTP

Goyo-ta-betchi'ibo.

Goyo-ACC-for

'Aurelia cooked the wakabaki for Goyo'.

(39c) Aurelia- $\emptyset \quad$ Goyo-ta u-ka wakabak-ta

Aurelia-NOM Goyo-ACC the-ACC wakabaki-ACC

joa-ria-k.

cook-APL-PASTP

'Aurelia cooked Goyo the wakabaki'.

Yaqui applicative clauses are restricted both syntactically and semantically. Semantically, they have the meaning associated with 'give' type verbs, i.e., ' $\mathrm{NP}_{1}$ causes $\mathrm{NP}_{2}$ to have $\mathrm{NP}_{3}$ ', where $\mathrm{NP}_{2}$ must be an animate participant. This restriction is responsible for the ill-formedness of the clause in $(40 b)$. In order to be grammatical, the propositional phrase must be used (40a). Structurally, the applicative can be added to intransitives, transitives, and Type A ditransitives, but not to Type B, as shown by the ill-formedness of the clause in $(40 c)$.

(40a) Karmen- $\emptyset \quad$ bwa'a-ta-betchi-ibo wakas-ta toja-k.

Carmen-NOM soup-ACC-for meat-ACC bring-PASTP

'Carmen brought the meat for the soup'.

$(40 b) *$ Karmen- $\emptyset$ bwa'a-ta wakas-ta toi-ria-k.

'Carmen brought the soup the meat'. 
(40c) *Goyo- $\emptyset$ Peo-ta toto'i-ta Lupe-ta miika-ria-k.

'Goyo gave Lupe the hen [for] Peter'.

In clauses where the RECIPIENT benefactive and theme are both animate, as in (41), the question arises about which of the two accusative arguments is the undergoer. As with three-argument verbs, the passive voice specifies which of the two nonactor direct core arguments corresponds to the undergoer: for the reading 'Goyo bought the bull for the benefit of the cow', it is the beneficiary argument, wakasta 'cow', which functions as the passive PSA (41b). The theme tooro 'bull' can serve as the passive PSA only when the beneficiary is coded within an oblique phrase $(41 d)$.

(41a) Goyo- $\emptyset \quad u$-ka wakas-ta $u$-ka tooro-ta

Goyo-NOM the-ACC cow-ACC the-ACC bull-ACC

jinu-ria-k.

buy-APL-PASTP

'Goyo bought the bull for the benefit of the cow'.

(41b) $U$ wakas- $\emptyset \quad u$-ka tooro-ta jinu-ria-wa-k.

the cow-NOM the-ACC bull-ACC buy-APL-PASTP

'The cow was benefited by the bull's being bought'.

(41c) *U tooro- $\emptyset$ u-ka wakas-ta jinu-ria-wa-k.

'The bull was benefited by the cow's being bought'.

(41d) $U$ tooro- $\emptyset \quad$ wakas-ta-betchi'ibo jinu-wa- $k$.

the bull-NOM bull-ACC-for buy-PASTP

'The bull was bought for the cow'.

In terms of the LS in (38c), the beneficiary wakas is the $y$ argument and the theme tooro is the $z$ argument; the $y$ argument, as the first argument of a two-place state predicate, is the second highest ranked argument in this LS in terms of the AUH. Hence, it is the undergoer.

4.2. Causative clauses. Causative clauses are also derived multiple object constructions. When the causative suffix -tua 'cause to do' is added to the verb, a new argument, the causer, is added to the clause and the original subject, the causee, is marked accusative. As shown below, the causative can be added to intransitive and transitive as well as the two types of ditransitive verbs.

(42a) Goyo- $\emptyset \quad$ Aurelia-ta a'at-tua-k.

Goyo-NOM Aurelia-ACC laugh-CAUSE-PASTP

'Goyo made Aurelia laugh'. 
$\begin{array}{lllll}\text { (42b) Goyo- } \emptyset & \text { im } & \text { chu'u-ta } & \text { nee } & \text { me'e-tua- } k . \\ \text { Goyo-NOM } & \text { 1SG:POSS } & \text { dog-ACC } & \text { 1SG:ACC } & \text { kill-CAUSE-PASTP }\end{array}$

'Goyo made me kill my dog'.

(42c) Lupe- $\emptyset \quad$ usi-ta mansana-ta yoem-ta-betana

Lupe-NOM child-ACC apple-ACC man-ACC-from

mabeta-tua-k.

receive-CAUSE-PASTP

'Lupe made the child receive the apple from the man'.

(42d) $U$ maejto- $\emptyset \quad$ usi-ta mansana-ta yoem-ta

the teacher-NOM child-ACC apple-ACC man-ACC

miik-tua-k.

give-CAUSE-PASTP

'The teacher made the child give the man the apple'.

Note that Yaqui derived verbs allow not only two nonactor direct core arguments, as in (42b) and (42c), but three accusative NPs also occur (42d). As in other multiple accusative constructions, the nonactor animate direct core argument, the causee, tends to precede not only the accusative theme but also the RECIPIENT. The LS of double-object me'e-tua 'make kill' and the triple-object miik-tua 'make give' predicates are shown below; the LS in $(43 b)$ corresponds to the reading 'the teacher made the child give the man the apple'.

(43a) me'e-tua

$\left[\mathbf{d o}^{\prime}(\right.$ Goyo-,$\left.\emptyset)\right]$ CAUSE $\left[\right.$ do' $\left.^{\prime}(1 \mathrm{sg}, \emptyset)\right]$ CAUSE [BECOME dead' (chu'u-)] ]

(43b) miik-tua

[do' (maejto-, Ø)] CAUSE [ [do' (usi-, Ø)] CAUSE [BECOME have' yoem-, mansana-)] ]

The causer is the highest ranking argument of the LS and therefore it is selected as actor and functions as the PSA in the active voice. ${ }^{14}$ In Yaqui, the causee is always accusative, together with the other direct core arguments of the basic verb. Consequently, the clauses in $(42 b)$ and $(42 d)$ present the same

\footnotetext{
${ }^{14}$ In the LSs in (43a) and (43b) there are two instances of the first argument of do' $(\mathrm{x}, \ldots)$; they are Goyo and the first-singular pronoun in (43a), while in (43b) they are maejto 'teacher' and usi 'child'. Why do Goyo and maejto outrank these other arguments for selection as actor? The answer is that they are the highest ranking arguments of the matrix LS, in these LSs, the LS for -tua 'causative'. The highest ranking argument of the matrix LS is always the actor in a clause with a complex LS like the ones in (43), as well as the ones in (46)-(48) below.
} 
question: which of the accusative NPs is the undergoer? It is the causee, the first argument of $\mathbf{d o}^{\prime}$ in the embedded LS in (43), and never the theme or RECIPIENT, that serves as the passive PSA; hence, the causee is the undergoer. ${ }^{15}$ Any other argument acting as the passive PSA is rejected. Below the passive versions of the clauses in $(42 b)$ and $(42 d)$ are shown, based on the LSs in (43).

(44a) Ne im chu'u-ta me'e-tua-wa-k.

1SG:NOM 1sG:POSS dog-ACC kill-CAUSE-PASS-PASTP

'I was made to kill my dog'.

$\left(44 a^{\prime}\right) * I m$ chu'u- $\emptyset$ nee me'e-tua-wa-k.

'My dog was made to be killed [by] me'.

$$
\begin{array}{lllll}
U & \text { usi- } \emptyset & \text { mansana-ta } & \text { yoem-ta } & \text { miik-tua-wa- } k \text {. } \\
\text { the } & \text { child-NOM } & \text { apple-ACC } & \text { man-ACC } & \text { give-CAUSE-PASS-PASTP }
\end{array}
$$

'The child was made to give the man the apple'.

$\left(44 b^{\prime}\right) * U$ yoeme- $\emptyset u$-ka usi-ta mansana-ta miika-tua-wa-k.

'The man was made to be given the apple by the child'.

$\left(44 b^{\prime \prime}\right) * U$ mansana- $\emptyset u$-ka usi-ta yoem-ta miika-tua-wa-k.

'The apple was made to be given [to] the man [by] the child'.

Accordingly, the passive version of a multiple-object causative clause requires the causee to act as the PSA. This selection is explained completely by the revised principle of undergoer selection. One more piece of evidence for the superiority of this principle comes from sentences like those in (45), where the causative and the applicative suffixes co-occur, increasing the valence of the basic verb by two. Recall that both human arguments, the causee and the beneficiary, have previously been selected as the undergoer, but here the causee is the only acceptable choice.

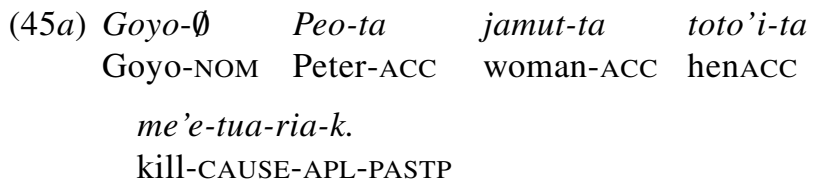

'Goyo made Peter kill the hen [for] the woman'.

${ }^{15}$ In $(43 b)$, the causee is the second highest ranking argument (the higher ranked argument is the actor), whereas the RECIPIENT is the second lowest; since the causee is selected as the undergoer over the RECIPIENT, this demonstrates the superiority of the undergoer as second highest argument principle, over the selection of the second lowest one. 


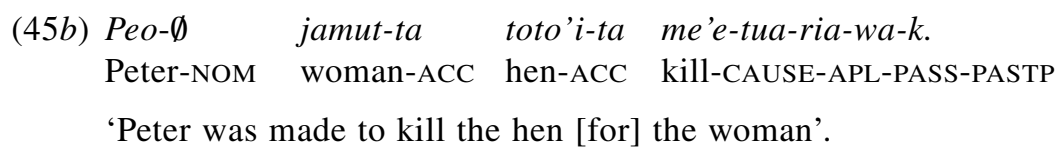

Besides the ambiguity when more than one argument is human, the preferred reading will be the one where the causee precedes the beneficiary. Here, the undergoer is assigned to the second highest ranking argument, the causee, leaving the beneficiary as a non-macrorole direct core argument.

4.3. Other valence-increasing constructions. Among the less common derivational suffixes are the desiderative -'ii'aa 'request, want' (46), the reported speech -tia 'claim, say that' (47), and the propositional attitude -maachia 'believe' (48). All these suffixes add an actor-type argument to the set of direct core arguments, altering the logical structure of the verb and, consequently, the assignment of macroroles.

(46) Desiderative constructions expressed by -'ii'aa

(46a) Fermin- $\emptyset \quad u$-ka chu'u-ta nee jinu-'ii'aa-k.

Fermin-NOM the-ACC dog-ACC 1sG:ACC buy-WANT-PASTP

'Fermin wanted me to buy a dog'.

(46b) Fermin- $\emptyset$ usi-ta mansana-ta yoem-ta

Fermin-NOM child-ACC apple-ACC man-ACC

u'ura-'ii'aa- $\emptyset$.

take.away-WANT-PRES

'Fermin wants the child to take the apple away [from] the man'.

(46c) want' $^{\prime}$ (Fermin-, [do' (usi-, Ø)] CAUSE [BECOME NOT have' (yoem-, mansana-)])

(47) Reported speech events expressed by -tia

(47a) Fermin- $\emptyset \quad u-k a \quad$ chu'u-ta nee

Fermin-NOM the-ACC dog-ACC 1SG:ACC

jinu-ne-tia- $k$.

buY-EXPECT-SAY-PASTP

'Fermin said I will buy a dog'.

(47b) Fermin- $\emptyset \quad$ usi-ta mansana-ta yoem-ta

Fermin-NOM child-ACC apple-ACC manACC

u'ura-tia- $\emptyset$.

take.away-SAY-PRES

'Fermin says the child is taking the apple away [from] the man'. 
(47c) do' (Fermin-, [say' (Fermin-, [do' (usi-, Ø)] CAUSE [BECOME NOT have' (yoem-, mansana-)])])

(48) Propositional attitude expressed by -maachia

(48a) Fermin- $\emptyset \quad u$-ka chu'u-ta nee jinu-maachia-k. Fermin-NOM the-ACC dog-ACC 1sG:ACC buy-BELIEVE-PASTP 'Fermin believed me to have bought a dog'.

(48b) Fermin- $\emptyset$ usi-ta mansana-ta yoem-ta

Fermin-NOM child-ACC apple-ACC manACC u'ura-maachia- $\emptyset$. take.away-BELIEVE-PRES

'Fermin believes the child to have taken the apple away [from] the man'.

(48c) believe' (Fermin-, [do' (usi-, Ø)] CAUSE [BECOME NOT have' (yoem-, mansana-)])

Similar constructions have been observed for other languages, e.g., Central Alaskan Yup'ik (Mithun 2000). The Yaqui data show that the suffixes -'ii'aa, -tia, and -maachia can be added to intransitive, transitive, and ditransitive bases. In all these constructions, the new argument functioning as the PSA in the active clause, the actor Fermin of the matrix verb, takes the nominative case, whereas all of the direct core arguments of the basic verb are accusative. Similar to the causative constructions, the undergoer is assigned to the second highest ranking argument, rather than the accusative theme or RECIPIENT. In the LSs in $(46 c)-(48 c)$, the second highest ranked argument in the entire LS is the highest ranked argument in the embedded LS. The examples below show the passive version of the Type-B-based constructions, where the passive PSA corresponds to the wanted, cited, and believed animate core arguments, respectively.

$$
\begin{aligned}
& U \text { usi- } \emptyset \text { mansana-ta } \\
& \text { the child-NOM apple-ACC } \\
& \text { man-ACC } \\
& \text { u'ura-'ii'aa-wa- } \emptyset \text {. } \\
& \text { take.away-WANT-PASS-PRES }
\end{aligned}
$$

'The child is wanted to take the apple away [from] the man'.

$U$ usi- $\emptyset \quad$ mansana-ta yeom-ta
the child-NOM apple-ACC man-ACC
u'ura-tia-wa- $\emptyset$.
take.away-SAY-PASS-PRES

'The child is said to take away the apple [from] the man'. 


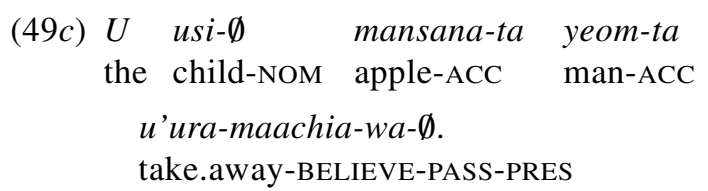

'The child is believed to take away the apple [from] the man'.

The superiority of the undergoer as second highest argument principle is even clearer when the applicative suffix -ria co-occurs with one of these derivational suffixes, adding two new accusative human arguments to the set of core arguments, where each of them has been previously selected in other complex constructions. The applicative version of the desiderative clause in (46a) is illustrated below; the LS in $(50 b)$ corresponds to the reading 'Fermin wanted me to buy Peter a dog' and its unique possible passive counterpart is shown in $(50 c)$.

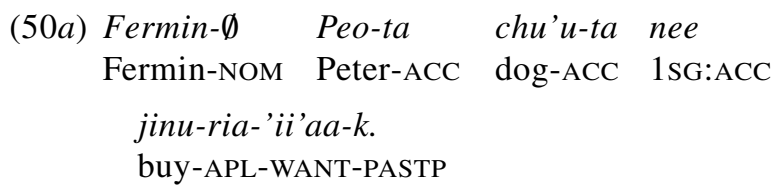

'Fermin wanted me to buy Peter a dog' or 'Fermin wanted Peter to buy me a dog'.

(50b) want' (Fermin-, [do' (1sg, Ø)] CAUSE [BECOME have' (1sg, chu'u-)] PURP [BECOME have' (Peo-, chu'u-)])
(50c) Nepo Peo-ta u-ka chu'u-ta
1sG:NOM Peter-ACC the-ACC dog-ACC
jinu-ria-'ii'aa-wa-k.
buy-APL-WANT-PASS-PASTP

'I was wanted to buy Peter a dog'.

For these four-argument derived verbs, it is the accusative agent-type argument that systematically serves as the undergoer, and so it is the passive PSA. This selection is successfully predicted by the revised principle since this agent-type argument occupies the first argument position of the $\mathbf{d o}^{\prime}$ predicate, a higher position compared to the RECIPIENT beneficiary, i.e., first argument of pred' $(\mathrm{x}, \mathrm{y})$.

5. Conclusion. We have shown that there are three different patterns of undergoer selection with verbs in Yaqui: Type A or the direct-indirect object pattern in (20), Type B or the primary object pattern in (23), and Type C or the locative alternation pattern in (27). English shows all three patterns too. English give and the other "dative shift" verbs show the Type A pattern 
in one of their uses, e.g., (1a), and there are many English verbs which show only this pattern, e.g., donate, put, and steal. The "dative shift" verbs also show the Type B pattern, as in (1b), and there are a few verbs in English which exhibit just the pattern in ( $1 b)$, i.e., the ditransitive pattern, e.g., envy, as in I envy him his money. Finally, there are many verbs in English that fall into Type C. Since both English and Yaqui have all three types of verbs, why is English considered to be a direct-indirect object language but Yaqui a primary object language? The answer is that the pattern of Type B verbs is not only found with several verbs in Yaqui, but it is the exclusive pattern found in all of the derived verb forms discussed in $\mathbf{4}$ above. In English, on the other hand, the Type B pattern is found most commonly with verbs which also exhibit the Type A pattern; there are very few verbs which show the Type B pattern exclusively, while there are more verbs that show the Type A pattern only. Yaqui is not a "pure" primary object language, due to the existence of Type $\mathrm{A}$ and Type $\mathrm{C}$ verbs in the language.

It should be noted that this contrast in undergoer selection patterns is independent of the privileged syntactic argument (subject) selection principles of the language. Both types are found in syntactically accusative and syntactically ergative languages. English and Yaqui are both syntactically accusative, while Dyirbal (an English-type language) and Belhare (a Yaquitype language; see Bickel 2002) are syntactically ergative. Given this typological fact, it is perhaps better to refer to these two types of languages as "indirect object" and "secondary object" languages, to avoid the potential problem of saying that, e.g., Dyirbal is a syntactically ergative, direct object language.

This analysis has important implications for the Actor-Undergoer Hierarchy in RRG: the principle governing the selection of the undergoer argument is different in secondary object languages from indirect object languages, and consequently the markedness relations expressed in figure 1 are not valid universally. Moreover, both patterns are found in the same language, as we have seen. Accordingly, undergoer selection principles in the hierarchy must be reformulated as in figure 2 .

The actor selection principle is the same as before. When the verb has only two arguments, then the two undergoer selection principles are equivalent and always pick out the same argument as undergoer, as shown in (37). When the verb has three or more arguments, then the difference between the two principles comes into play, yielding the different patterns with threeargument verbs discussed in this paper. Clearly, in Yaqui, both principles are operative: some lexical verbs follow Principle B, some verbs take Principle A as an absolute, not as a default, e.g., nenka 'sell', while others take Principle A as a default only, e.g., chijakta 'sprinkle', and this is expressed as Principle C. No verbs take Principle B as just the default pattern. Principle 


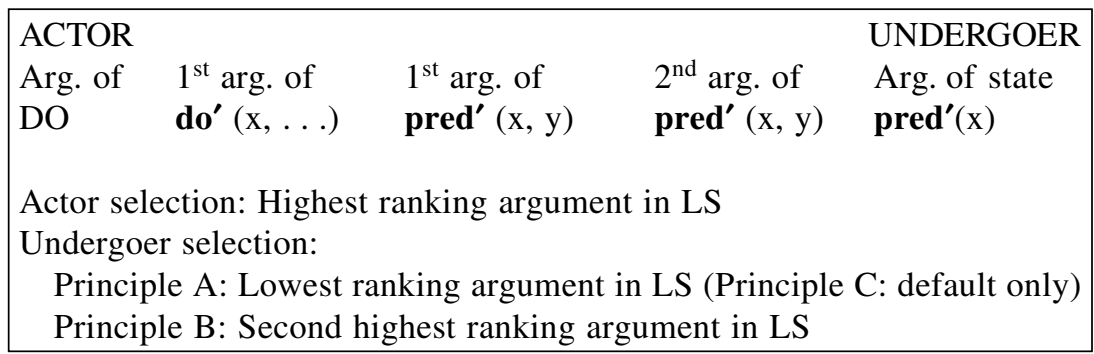

FIG. 2.-Actor-Undergoer Hierarchy (revised).

B also accounts straightforwardly for multi-transitive verbs, as shown in $\mathbf{4}$ above. For English, on the other hand, the majority of three-argument verbs follow Principle C, i.e., they take Principle A as the default pattern but permit an argument other than the lowest ranked to be selected as the undergoer. There are some which follow Principle A, e.g., donate, put, and steal, and there is an even smaller group that follows Principle B, e.g., envy. Thus, the contrast between indirect object and secondary object languages is not absolute but rather one of degree, depending on which of the undergoer selection principles in figure 2 is dominant in the language.

\section{REFERENCES}

Bickel, Balthasar. 2002. Belhare. The Sino-Tibetan Languages, ed. Graham Thurgood and Randy J. LaPolla, pp. 546-70. London: Routledge.

Comrie, Bernard. 1982. Grammatical relations in Huichol. Syntax and Semantics: Studies in Transitivity, ed. Paul Hopper and Sandra Thompson, pp. 95-115. New York: Academic Press.

Dedrick, John M., And Eugene H. Casad. 1999. Sonora Yaqui Language Structure. Tucson: University of Arizona Press.

Dryer, Matthew. 1986. Primary objects, secondary objects, and antidative. Language 62:808-45.

Escalante, Fernando. 1990. Voice and argument structure in Yaqui. Ph.D. dissertation, University of Arizona.

Estrada, Zarina. 1998. Aspectos lingüísticos del Yaqui. Jiak nikpo e’tejoim: pláticas en Yaqui, ed. Silva Encinas, Alvarez Romero, and Buitimea Valenzuela, pp. 123-40. México: Universidad de Sonora.

2003. Cambio de valencia: morfología derivativa en construcciones incoativas, aplicativas y causativas en pima bajo. Paper presenter at I Seminario de voz. México: Universidad de Sonora.

Estrada, Zarina; et AL. 2003. Diccionario Yaqui-Español y textos: Obra de preservación lingüística. México: Plaza y Valdés.

Guerrero, Lilián. 2001. Macrorole assignment in three-place predicates in Yaqui. Proceedings from the 2001 Niagara Linguistic Society, ed. Tom McClive and Todd McDaniels, pp. 1-17. Buffalo: University at Buffalo, State University of New York. 
2002. Complex constructions and macrorole assignment in Yaqui. Paper presented at the Role and Reference Grammar Conference, Madrid.

Holisky, Dee A. 1987. The case of the intransitive subject in Tsova-Tush (Batsbi). Lingua 71:103-32.

Koenig, JeAn-Pierre, and Anthony R. Davis. 2001. Sublexical modality and the structure of lexical semantics representations. Linguistics and Philosophy 24:71-124.

LANGACKER, RONALD. 1977. Studies in Uto-Aztecan Grammar: An Overview of Uto-Aztecan Grammar. Vol. 1. Dallas: Summer Institute of Linguistics and the University of Texas at Arlington.

Levin, Beth. 1993. English Verb Classes and Alternation: A Preliminary Investigation. Chicago: University of Chicago Press.

Levin, Beth, and Malka Rappaport-Hovav. 1995. Unaccusativity: At the Syntax-Lexical Semantic Interface. Cambridge, Mass.: The M.I.T. Press.

2002. What alternates in the dative alternation? Paper presented at the Role and Reference Grammar Conference, Madrid.

LiNDENFELD, JACQUELINE. 1973. Yaqui Syntax. UCPL 76. Berkeley and Los Angeles: University of California Press.

Mithun, Marianne. 2000. Valency-changing derivation in Central Alaskan Yupi'k. Changing Valency: Case Studies in Transitivity, ed. R. M. W. Dixon and Alexandra Y. Aikhenvald, pp. 84-114. Cambridge: Cambridge University Press.

Rude, Noel. 1996. Cláusulas de objetos dobles en yaqui. Memorias del III Encuentro de Lingüística del Noroeste, pp. 191-214. México: Universidad de Sonora.

Shibatani, Masayoshi. 1996. Applicatives and benefactives: A cognitive account. Grammatical Constructions: Their Form and Meaning, ed. Masayoshi Shibatani and Sandra Thompson, pp. 157-94. Oxford: Clarendon Press.

Van Valin, Robert D., JR. 2001. The Role and Reference Grammar analysis on three-place predicates. Paper presented at the Role and Reference Grammar Conference, University of California, Santa Barbara.

Van Valin, Robert D., JR., And Randy J. LaPolla. 1997. Syntax: Structure, Meaning and Function. Cambridge: Cambridge University Press.

VAn Valin, Robert D., JR., ANd DaVid Wilkins. 1996. The case for 'effector': Case roles, agents and agency revised. Grammatical Constructions: Their Form and Meaning, ed. Masayoshi Shibatani and Sandra Thompson, pp. 289-322. Oxford: Clarendon Press.

VÁzQuez, Veronica. 1996. El participante no sujeto en Cora: orden de palabras, codificación y marcación de número. Memorias del III Encuentro de Lingüística del Noroeste, pp. 533-54. México: Universidad de Sonora.

Vendler, Zeno. 1967. Linguistics in Philosophy. Ithaca, N.Y.: Cornell University Press. 